\title{
What is to be Done? Framings of Urban Populism in Prague and Warsaw
}

Conor O’Dwyer*

A R T I C LE INFO

Received:

July 12, 2021

Received in revised

form:

October 30, 2021

Accepted:

November 7, 2021

Published online:

November 27, 2021
A B S T R A C T

Resurgent populism in East Central Europe is typically analyzed at the national level. This paper examines populist urban movements in two of the region's capital cities: Prague and Warsaw. It locates the origin of urban populist grievances in the crisis of urban-planning regimes after communism. At the same time, it argues that the character of populist urban movements, in terms of their mobilizing frames and tactics, varies between cities depending on the openness of municipal institutions to new social actors. The research draws on extensive field interviews, policy documents, academic analyses, and domestic media reports. It sheds light on an under-studied variant of post-communist populism - one less conservative and potentially more inclusive - and contributes to the literatures on postcommunist civil society, urban planning, and municipallevel politics.

Keywords: Urban movements, urban planning, populism, municipal politics, post-socialist city.

To cite this article: O'Dwyer, C. (2021). What is to be Done? Framings of Urban Populism in Prague and Warsaw. Urbana, 22, 40-62. Retrieved from http://www.urbanauapp.org

https://doi.org/10.47785/urbana.6.2021

\footnotetext{
* Professor of Political Science at the University of Florida. codwyer@ufl.edu
} 


\section{Introduction}

Since communism fell in Eastern Europe, an interdisciplinary scholarship has described a distinctive urban type, the "post-socialist city," whose ongoing restructuring reflects socialism's economic, political, and cultural legacies as well as the birth pains of the transition (Sýkora and Bouzarovski 2012, 44). Economically, the post-socialist city epitomizes unbounded neoliberalism, the result of the intentional weakening of urban planning institutions as relics of communist planning in the early 1990s (Lorens 2006; Walter 2006). Politically, the post-socialist city is typified by party capture of such urban planning institutions as remain for clientelist purposes and, consequently, unresponsiveness and unaccountability to the public (Horak 2007). At the societal level, the post-socialist city's collective and public spaces are described as degraded (viz. overly-commercialized city centers and visual smog) or privatized (viz. the explosion of gated communities), developments attributed to a culture of "privatism" (Hirt 2012). It is an overwhelmingly negative portrait, succinctly encapsulated by the title of Joanna Kusiak's influential study of post-1989 Warsaw, Chaos Warszawa (2017).

In more recent literature, however, a potentially more positive development has also been noted, namely, the emergence of urban grassroots movements targeting these dysfunctionalities (Kusiak 2017; Pixová 2020). As the sociologist Kerstin Jacobsson notes, urban movements have been a feature of West European and American cities for many years and a variety of terms has been used to describe them, e.g. "urban activism" and "urban grassroots mobilizations." Beneath these various labels is a uniting concern "with shaping the life in the city (Jacobsson 2015, 7). More specifically, such movements "consider themselves urban...in their self-denomination... are locally based and territorially defined..., and [t]hey mobilize around [at least one of] three major goals: collective consumption (or public infrastructure), cultural identity, and political self-management" (Jacobsson 2015, 7). Being participatory, bottom-up, and oriented domestically (not internationally), postsocialist urban movements also challenge "the (still dominant) picture of the overly professionalized and advocacy-oriented NGOs as the main civil society actors in the postsocialist context as well as the frequently noted difficulties in mobilizing grassroots in this region" (Jacobsson 2015, 5; cf. Polanska 2015, 195).

In Prague and Warsaw, the focus of this essay's research, urban movements rose to prominence beginning around 2010 as part of a broader upswing in civil societal engagement, public protests, and trade union mobilization in East Central Europe following the European financial crisis (Guasti 2016). A common focus of this mobilization was the perceived corruption and unresponsiveness of established political elites (Guasti 2016, 227 229), and in this respect, both cities' urban movements paralleled the surge in national-level populist political parties in much of the region at this time. Yet, whereas national-level populism has often led to democratic backsliding, urban movements - though also directed against perceptions of corrupt and unresponsive elites - have been seen as progressive populists, enhancing democracy by revitalizing municipal institutions neglected after 1989 (Jacobsson 2015; Kusiak 2017; Pixová 2020, 32; Polanska 2015).

This paper addresses the question: what kind of populism do post-socialist urban movements espouse and why? If we accept that populism can take various forms, from democratically-oriented "common sense" reformism to contentious critique of the status quo 
to authoritarian-tending illiberalism, then where on this spectrum do the region's urban movements locate themselves? To what extent does the answer to this question depend on the perceived problems of municipal governance, on the one hand, and on the opportunities available for collective action in the local political system, on the other? My approach is descriptive and inductive. I characterize the predominant strategic orientation of urban movements by analyzing which mobilizing frames and associated tactics resonate most in a given context.

By virtue of their pre-1989 history and, as I will argue, their history since 1989, Prague and Warsaw represent divergent political contexts for post-socialist urban movements. Thus, they allow us to explore the range of possibilities for this less-studied form of populism. I argue that, in Warsaw, the combination of a laissez-faire urban-planning regime and a local party system closed to new actors leads urban activists to use more radical mobilizing frames and disruptive tactics. By contrast, in Prague, the combination of institutional continuity in urban planning and a more open party system gives greater resonance to reform-populist frames and more conventional pressure-group tactics. I present three types of empirical evidence to build this comparative portrait. First, I draw on 66 field interviews conducted with planners, civil society activists, politicians, architects, developers, academics, journalists, and business people in both cities in 2018 and 2019 (see the appendix for details). I also rely on policy documents, media reports, academic analyses by participants in each city's urbanist milieu and the broader secondary literature.

The next section presents the paper's theoretical framework. The following two empirical sections compare the political contexts facing Prague and Warsaw's urban movements, focusing on the crisis of each's urban-planning regime but also differences in the degree to which activists can find access to municipal institutions in each city. The empirical analysis then traces the implications of these differing contexts on the mobilizing frames and tactical styles of urban activists since 2010. I conclude with reflections on the research's contributions to the broader literatures on civil society, the post-socialist city, and contemporary populism in Eastern Europe.

\section{Theoretical framework}

This section adapts social movement scholar Mario Diani's (1996) work on Italian populism in the 1980s-90s, to show how two factors shaped divergent framings in the urban movements of Prague and Warsaw. These factors are (1) social grievances created by the urban-planning regime, which serve as opportunities for urban movements to mobilize, and (2) the accessibility of the political system to new political actors. First, however, I describe how I conceptualize populism and the range of possible strategic orientations for urban movements within it.

Populism is a notoriously slippery term because it has been applied to groups as diverse as the left-leaning Peronists of postwar Argentina, the agrarian People's Party in the 19th-century United States, and the radical right in contemporary Europe (Mudde and Rovira Kaltwasser 2013), not to mention urban activists such as the slow-growth movement in San Francisco (DeLeon and Powell 1989). As the political scientists Cas Mudde and Cristóbal Rovira Kaltwasser argue, ideological flexibility and the ability to transcend left-right labels are populism's defining features. It is a "thin-centered ideology," defined in terms of three 
primary features: valorization of "the people," critique of "corrupt elites," and a preference for bottom-up participation and "common sense" over representative or technocratic institutions (Mudde and Rovira Kaltwasser 2013: 498-505). Post-socialist urban movements offer many resonances on these chords. The theme of elevating the people is evident even in the name of Warsaw's main urban movement "The City Is Ours" - as is the implicit antielitism (ours the people's, not theirs the politicians', developers', etc.). Geographer Michaela Pixová's (2020) study of urban movements in Prague and other Czech cities notes their "frequent tendency ...to use populist discourses as a tactic which transforms their grievances into the shared identity of large groups of citizens who are disillusioned by the policy outcomes of post-socialist urban governments" (2020,176). As noted earlier, these movements are more participatory, less professionalized, and more domestically oriented than post-communist civil society groups tend to be.

Populism's ideological vagueness means that populists can appeal to citizens of all partisan stripes and that the range of strategic orientations from which they may choose is extremely wide. It is an important point, though one often obscured by the authoritarian tendencies of national-level populist governments such as Poland's or Hungary's, that populism can also be a "democratizing force" (Mudde and Rovira Kaltwasser 2013, 506). As Mudde and Kaltwasser write, "the democratic side of populism relies on its capacity to give voice to groups that, objectively or subjectively, are being excluded from the collective decision-making process" $(2013,506)$. This paper begins from the premise that urban populist movements may favor different mobilizing frames and tactics - some more radical and disruptive, some more reformist and routine - depending on local political context.

To better theorize how context matters, I draw on the concept of political opportunity structure (POS), which Sidney Tarrow defines as those "dimensions of the political environment that provide incentives for people to undertake collective action by affecting their expectations for success" $(1994,85)$. As this definition suggests, POS is often used to explain the emergence of collective action in and of itself. Scholars also recognize, however, that POS affects how social movements develop, in particular, how they use "framing" to diagnose grievances and mobilize participants (Diani 1996; Snow and Benford 1992). Framing is an interpretive, deliberative, and negotiated process in which social movement actors identify and problematize a social condition, attribute blame and responsibility for it, and persuade others to act collectively to effect change (Benford and Snow 2000: 615). In mobilizing to effect change, framing is closely aligned with tactics and strategy. Since for any given grievance multiple possible frames are possible, finding one that resonates, i.e. that can mobilize potential supporters, is an important strategic choice. David Snow and Robert Benford (1992) argue that social movements whose mobilizing frames offer the greatest fit with the "master frame" of a protest cycle enjoy greater success in achieving their desired outcomes. Building on this insight, Mario Diani (1996) offers a framework that operationalizes the notion of frame fit with different possible configurations of the POS.

Figure 1 adapts Diani's typology to urban movements, disaggregating the POS into two elements: (1) the opportunities created by the crisis of the extant urban-planning regime and (2) the opportunities for autonomous action within the institutions of city politics. Varying these elements yields four ideal-typical political contexts, or master frames. The fidelity of a given social movement organization's mobilizing frame and tactics to the 
relevant master frame determines its degree of resonance in the wider political system. I will focus on "realignment" and "anti-system" master frames since they best describe the contexts facing urban movements in Prague and Warsaw.

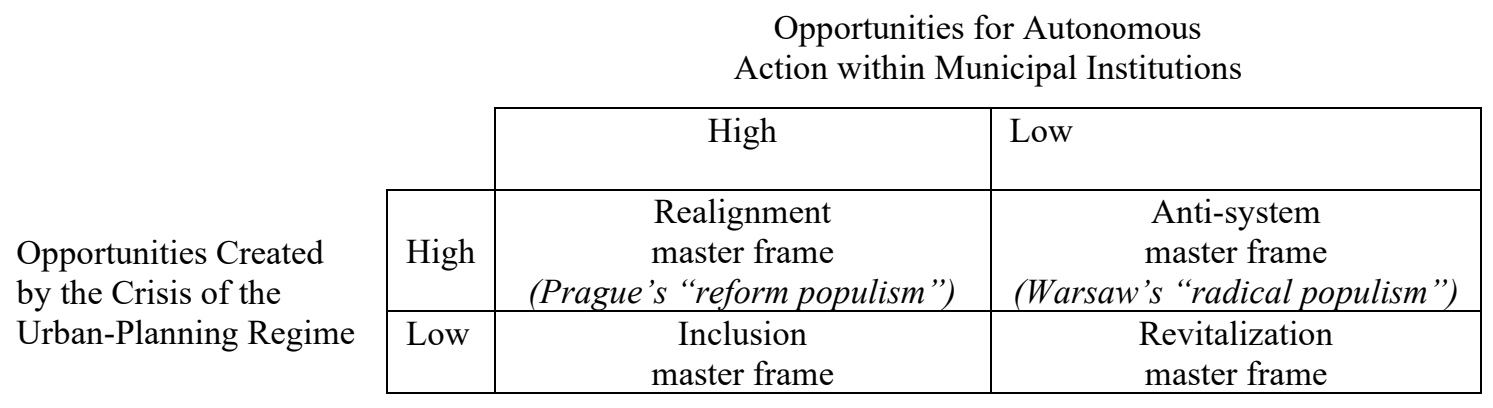

Fig 1. Master Frames and the Political Opportunity Structure

Source: Adapted from Diani $(1996,1056)$

Both of these ideal-typical master frames occur when there is a sense of crisis in the urban-planning regime. Depending on the accessibility of municipal institutions, however, crises of the urban-planning regime will favor either master frames of realignment or antisystemic opposition. Where, "the perception of ample opportunities for collective action" combines with "decreasing capacities of traditional alignments [and institutions] to structure political action," it creates a realignment master frame, which is defined by "the need to restructure political systems on the basis of new collective identities without a global delegitimation of the established members and procedures of the polity" (Diani 1996, 1056). Social movement organizations working within the political logic of a realignment master frame are likely to adopt a "democratic populist" orientation (Diani 1996, 1056). In terms of the strategic orientation of such organizations, we would expect those of "the participatory pressure group" (Diani and Donato 1999, 17), that is, a focus on bringing the concerned citizen into the work of city governance but also working non-confrontationally through conventional institutions and procedures, e.g. organizing petitions, lobbying, etc. When, however, crisis prevails but avenues for challenging elites appear closed, the master frame favors challengers advocating a "more radical transformation of the polity...defin[ing] political actors along lines other than the established cleavages and den[ying] legitimacy to the routinized functioning of the political process" (Diani 1996, 1057). By this anti-system logic, we would expect social movement organizations characterized by confrontational and disruptive tactics, the "participatory protest organization" type (Diani and Donato 1999, 17). At the extreme end, we would expect illiberal-backlash populism here: consider the Lega Nord party described in Diani's analysis or the national-level Law and Justice party in Poland. To be clear, we do not find illiberal-backlash populism in Prague or Warsaw's urban movements. But we could also include less extreme populist orientations within the "antisystem" master frame, groups whose mobilizing frames do not take the critique of the status quo as far as illiberalism, but which nevertheless portray reformist tactics as ill-suited to achieving desired change. This kind of framing we do find in our sample. In sum, both realignment and anti-system master frames are compatible with populism, but the former's "reform populism" lays greater emphasis on giving "voice to groups that...are being excluded from the collective decision-making process" (Mudde and Rovira Kaltwasser 
2013, 506) while the latter's - call it "radical populism" - is defined more by its disruptive tactics and critique of extant institutions.

As depicted in Figure 1 and described below, Prague and Warsaw both experienced a crisis of the urban-planning regime in the aftermath of the 2010 financial crisis, as city residents came to see municipal institutions as unresponsive and captured by special interests. They differed sharply on the second dimension, however. In Prague, the implosion of the local branches of the established Czech political parties opened opportunities for grassroots populist movements to unseat incumbents in city councils. In Warsaw, by contrast, the established parties maintained their control, and municipal institutions were less open to challengers from below. Thus, Prague's post-socialist urban activism tended toward reformism and a comparatively successful campaign to restructure the planning regime, whereas Warsaw's embraced a more radical populism without, however, effecting much institutional change.

\section{Post-socialist urban-planning regimes as incubators of populist grievances}

By 2010, crises of legitimacy pervaded the urban-planning regimes of both Prague and Warsaw. The path to crisis was different, as this section describes, but the endpoint was the same: a widespread sense that municipal institutions responsible for guiding construction, infrastructure planning, and public amenities were unaccountable to citizens, having been captured by monied interests and political parties. That this outcome was possible despite the quite different structuring principles that had come to govern each urban-planning regime after 1989 - laissez-fair in Warsaw, technocratic in Prague - offers a useful theoretical lesson about the relationship between "transition" and urban planning. In Prague, planning institutions and principles retained some strong continuities with the socialist era, and thus maintained greater influence over development (Horak 2007; Maier 1998; Roubal 2019). As pointed out in my interviews, Prague's city government is still working off a Master Plan whose core features were drawn up in 1976 and only incrementally modified since (Interview P19-38; Horak 2007, 135). Ironically, these continuities survived a deep skepticism for urban planning as a communist-era relic; in the 1990s, Prime Minister Vacláv Klaus was known for his "Margaret Thatcher attitude to planning" (Hoffman 1994, 695). If, as Sonia Hirt $(2012,76)$ has argued, it is not uncommon for post-communist countries to change the institutions of planning while leaving core principles of the planning regime (such as detailed functional planning intact), then Prague offers a good case study of this type. In Warsaw, by contrast, the most important elements of the socialist-era planning regime were dismantled after 1989, privileging private actors and leading to a style of development often described as both "chaotic" and market-dominated (Kusiak 2017; Lorens 2006; Interviews W19-17, W19-12, W19-19). Ironically, both trajectories proved compatible with clientelistic planning practices and unresponsiveness to citizens. Thus, both laissez-faire and technocratic urbanplanning regimes became incubators for populist grievances, with the 2008-2010 financial crisis then serving as a critical juncture allowing urban movements to challenge political elites in both.

\section{Prague}

Many unflattering words have been used to describe Prague's urban-planning regime - 
unresponsive, clientelistic, pro-developer - but the term of choice for Warsaw, "chaotic," is not one of them. Instead, Czech historian Petr Roubal (2019) describes a system best encapsulated by the word "conservative," especially before 2010: planners saw themselves as preservationists (or even restorationists) of the pre-communist city, not as shapers of its future. This conception was captured in the principles underlying the city's first postrevolution spatial plan in 1992, whose main goal was to delineate "stabilization zones" in which construction would be halted. Decisions about the city's future development were left for the future (Roubal 2019, 340). In practice, these stabilization zones consisted of the vast communist-era prefabricated housing estates in the city periphery. Hostility to the housing estates was accompanied by idealization of the city's historic core, including the 19thcentury band around the core: a memorial zone encompassing both and strictly limiting construction was proclaimed in 1993 (Roubal 2019, 339). The goal of this "self-limiting city planning," in Roubal's memorable phrase, was to remove the results of the communist-era urban-planning regime. It was captured in the text of the 1992 spatial plan itself, which stated, "it's not possible to expect a transformational new urbanistic conception in Prague" and that planners should instead aim for the "harmonic renewal of the city with an emphasis on preserving its historical and natural values and endowments" (quoted in Roubal 2019, 340). This skepticism toward urban planning as a tool for proactively shaping the city was, Roubal argues, part of a longer process of disenchantment with planning that had begun in the 1970s-80s, intensified by grass-roots opposition to the large-scale development plans of Czechslovakia's hardline Communist Party.

Roubal's argument notwithstanding, it would be a mistake to conflate skepticism toward proactive planning with lack of influence over how the city develops. This Prague's planners retained, if only to constrain unwanted development, or to shift it to the suburbs. For example, the city's Chief Architect Ivo Oberstein retained the power to block building permissions for any project, and he used it extensively in the early 1990s. Even after the Office of the Chief Architect was abolished in 1994, by comparison with Warsaw, Prague's urban-planning regime was much less subject to reform initiatives after 1989. In his study of Prague politics in the 1990s, Martin Horak (2006) described an urban-planning regime that, due to deadlock over how to reform pre-1989 planning principles, remained a top-down system that isolated planners and other experts from the public. It also became, Horak shows, increasingly clientelistic in practice. Three factors fed this development.

The first was institutional. As in Poland, political institutions were decentralized after 1989, which granted extensive powers and properties to municipal governments and agencies. In both countries, this decentralization damaged the capacity for urban planning because municipal governments lacked the professional expertise, financial resources, or ideological inclination to engage in it (Hoffman 1994; Maier 1998). The degree to which early 1990s decentralization constrained the urban planning capacity of the capital cities differed in both countries, however. In Warsaw, decentralization was particularly damaging to the urban-planning regime because the city itself was decentralized, that is, internally fragmented (see below). By contrast, Prague's city-wide governmental institutions, the socalled Magistrát, were able to preserve their unity (Roubal 2019, 338). As mentioned earlier, the Chief Architect's Office was abolished in In 1994, but its functions were transferred to a new City Development Authority (URM henceforth) and Territorial Planning Section, both 
part of the Magistrát (Kanceláŕ 2014, 193, 205). The first major legislative change to the urban planning system was not until 2006, when the national building code mandated that municipalities update their master plans within five years. The first initiative to update the city's Master Plan, "Concept 2009," did not begin until 2007, and it retained the functional planning model, the second factor on which Prague's technocratic clientelism came to rest.

Prague's land-use continued to be governed by a Master Plan and zoning methodology developed before 1989. The system rested on an elaborate set of over thirty functional land-use categories, with additional subcategories (Pixová 2020, 44). Any new construction usually required detailed changes to the Master Plan, which in turn required such proposals to pass through multiple levels of administrative review before being voted on as legislative items in the city council. In multiple interviews, I was informed that, because of this complicated process, it generally required 10 years to receive building permits. Combined with the already mentioned tendency to conserve the old and block the new, this urban-planning regime drove up the price of land, increasing the value of political connections that could expedite zoning and building permissions. The influx of foreign investment after 1989 only heightened it more. As Czech urban geographer Michael Pixová wrote, "Some politicians quickly realized that they could also profit from the brokerage of their decision-making power over the existing regulatory framework" $(2020,42)$."

The third element undergirding this technocratic-clientelist urban-planning regime was a political party machine that captured the Magistrát in the mid-1990s. The conservative Civic Democratic Party (ODS) ran the machine, initially on its own but, when needed, with the support of the Social Democrats. These parties were programmatically opposed, but political rents held the cartel together (Horak 2006, 142-3). The first decade of the 2000s was the heyday of the ODS-led machine, culminating in an absolute majority in the 2006 elections. Martin Horak (2007) has shown how the ODS machine captured municipal institutions. One example was the Historic Preservation Office, an official from which recounted in 2000, "This institution has basically been turned into a business run by [one long-time official]. He's the one who is in charge, who decides which investors will have to pay for the privilege of getting their way" (quoted in Horak 2007, 168). ODS provided the "umbrella under which they [corrupt officials and politicians] could find protection" (Horak 2007, 175). Numerous of my respondents described ODS mayor Pavel Bém's tenure (20022010) as the apogee of this machine politics.

\section{Warsaw}

In 2004, architect Adam Kowalewski described Warsaw's urban planning as “"spatial chaos' in an "ugly city"' (quoted in Walter 2006, 259). Kowalewski was addressing a conference reflecting on the first 15 years of post-1989 planning. It found a planning crisis comprising "unregulated greenfield development"; "uncontrolled and uncoordinated increase in building densities and heights and the chaotic development of public spaces and central areas"; runaway suburbanization of forest land outside the center; and "severe neglect of the postwar large-scale housing estates" $(2006,259)$. Even as further problems like visual smog and traffic were added in the following fifteen years, the common denominator remained the term "chaos." According to urban sociologist Joanna Kusiak, "chaos" is "the key word in the Polish public debate about cities" $(2017,12)$. 
Chaos is the spatial manifestation of what I term a laissez-faire urban-planning regime, in which market forces determine the trajectory of development largely untrammeled by municipal planners. As Mareile Walter writes of 1990s Warsaw, "Market forces reigned supreme. Shopping parks, leisure complexes, offices and commercial facilities were built wherever a developer wanted" (2006, 259). Unlike the Czech Republic, there were several major attempts in Poland to legislate a new framework for planning (see Table 1), but, as one official in a Warsaw city planning agency put it to me in 2019:

All the parliamentary legislation [since 1989] has gradually dissolved the planning system. And this famous 2003 Planning Act - which we unfortunately have to work with today (still!) - is actually, let's say, a parody of a planning system. I mean, theoretically it is a planning system, but it has so many holes that it contradicts itself. For example, on the one hand, it says, we have to build our cities through local plans. Well, but if there is no local plan, you can build without a local plan. So the question is, what do we need these local plans for? And it puts local governments in the position that they have to race with private investors. Who will be faster? The city trying to make a local plan or the investor, who is pushing his investment through...The effects are disastrous. (Interview W19-19)

The path to this outcome was institutional mis-sequencing: political decentralization and economic liberalization typically proceeded several steps ahead of urban-planning reforms, with the result that the instruments of urban planning were rendered impotent by the time they were introduced because economic realities had already changed. Unlike in Prague, Poland's reforms did not maintain technocrats' influence over Warsaw's planning regime. Instead, it disempowered both technocrats and activists, making private developers (and sometimes municipal politicians) the deciding actors. EU accession only intensified the sense of "spatial chaos" because it increased the volume of infrastructural investments at precisely the moment that deregulatory trends in urban planning were cresting: from the mid2000s Poland resembled one huge construction site.

\begin{tabular}{l|l|l}
\hline Year & Political-Market Reforms & Urban Planning Reforms \\
\hline 1985 & & $\begin{array}{l}\text { Planning Act (mandates "general plans" for } \\
\text { municipalities) }\end{array}$ \\
\hline 1992 & $\begin{array}{l}1^{\text {st }} \text { Decentralization Reform (establishes } \\
\text { local governments (gminy) with planning } \\
\text { authority but few resources) }\end{array}$ & $\begin{array}{l}\text { Planning Act (mandates "local plans" but allows for } \\
\text { provisional "studiums" in their stead) }\end{array}$ \\
\hline 1994 & $\begin{array}{l}\text { 2nd Decentralization Reform (establishes } \\
\text { regional government and administration, but } \\
\text { not accompanied by budgetary } \\
\text { decentralization) }\end{array}$ & \\
\hline 1998 & & $\begin{array}{l}\text { Planning Act (introduces "administrative decisions" } \\
\text { procedure) }\end{array}$ \\
\hline
\end{tabular}

Table 1: Timeline of Significant Changes to Warsaw's Urban-Planning Regime 
Warsaw's path to a laissez-faire planning system began as early as the transition itself. In May 1990, the Solidarity government undertook to reverse the centralization of the communist state by re-establishing independent local governments, the gminy, to whom planning authority was devolved over the following two years (Loren 2006, 99; Walter 2006, 261). As noted earlier, most municipalities lacked either the professional expertise, financial resources, or ideological inclination to pursue active urban planning (Loren 2006, 101; Interview W19-3). Decentralization also allocated a large amount of state-owned property to the gminy, which could be sold off to private interests to raise money: even when this reprivatization did not arouse suspicions of clientelism, it typically did not constrain the new private owners in terms of some larger public vision, creating an "investors' dictatorship" (Walter 2006, 262).

The decentralization of Warsaw represented an extreme version of this abnegation of urban planning because of the way administrative boundaries were redrawn, breaking up the city into stand-alone gminy which then found it impossible to coordinate priorities. In 1999, Warsaw's internal boundaries were redrawn again. Marceil Walter described the results thus:

Warsaw now comprised four independent administrative levels: two parallel ones covering the whole city (the county and the association [of gminas], the 18 communities [gminas] of the city and the eight districts of Central Warsaw. The council of the Communities' Association had lost almost all influence on the independent communities, each of which had their own plans and projects.

(Walter, 2006, p.262)

The dysfunctionality of this arrangement led to another reorganization in 2002, which unified central Warsaw into one municipal government county-level (powiat) status. It was after this change that the city gained a single mayor (Prezydent) and city council. This remains the arrangement in effect to this day.

The collapse of communism in 1989 brought transformative changes to the local economy and polity. The introduction of private property and the privatization of state assets meant that the city's built environment could now be shaped by private investors rather than public officials. Poland's radical decentralization of the political system moved the bulk of decisions about local development from national and regional authorities to new elected local governments. Despite these changes to economic and political institutions, the instruments of urban planning were still defined by a law from 1985, the National Act on Spatial Planning (Buczek 2013,6). Thus, local governments were working with urban planning tools designed for a centrally planned economy.

Ironically, these tools proved very friendly to private developers in the early 1990s, especially those building suburban housing in green zones ringing the city. First, the 1985 Planning Act only required municipalities to have a "general plan," grouping land use into a few roughly defined categories (Lorens 2006, 98-99). Second, the Act assumed that most land was state-owned (Buczek 2013). Consequently, neither planners nor developers were constrained by the need to compensate private owners for costs imposed by planning or building decisions; nor was there a metric by which such compensation would occur. A related problem was that in 1985, when these urban planning instruments were introduced, 
they rested on assumptions about the responsibilities of business enterprises that were no longer tenable in the 1990s. For example, communist-era enterprises, especially the larger ones, typically provided a variety of social services to their employees, such as day-care and health care clinics. Such social infrastructure could be assumed when an area was zoned for commercial use. Not so after 1989. Practically speaking, the gap between the establishment of local governments and private property, on the one hand, and updated urban planning instruments on the other made local urban planning easy and cheap between 1989 and 1994.

Many municipal governments took advantage of their new powers to zone large areas for residential and industrial development in anticipation of future needs. They were further incentivized to move quickly, even if using the often outdated assumptions of the 1985 tools, by the fact that public discussion of new zoning legislation was already underway, and it was clear that that legislation would make planning more expensive and more open to public scrutiny (Buczek 2013, 7- 8).

A National Act on Spatial Development took effect in 1994 (Buczek 2013, 8). While the Act was intended to reorient urban planning instruments to market-democratic conditions and not to eliminate them, skeptics may be forgiven for missing the difference. If planning instruments still existed in theory, they appeared irrelevant in practice.

The 1994 Act obligated spatial plans to incorporate the financial and cost implications of development decisions. This change made planning a far more complicated and expensive exercise. Undermining the idea of more careful planning, however, the 1994 law also removed the requirement that municipalities produce spatial plans at all. Instead, they were only required to produce a so-called studium, or "study of conditions and directions of urban development of the municipality" (Lorens 2006, 99). This was not a legally binding document that could serve as the basis for zoning land and making decisions about building permits, as a spatial plan would. It was instead a kind of declaration of general principles to guide development. It was also intended to serve as the basis for drawing up more realistic spatial plans, "local plans," later. These local spatial plans would be legally binding and govern the kind of building at the plot level, and each municipality would be required to have one within five years, by 1999. After this point, the old, pre-1994 spatial plans would be rendered invalid.

In practice, by prolonging the validity of the 1985-era plans for another five years, the 1994 Act did nothing to alter the dominant trends in development, especially regarding unregulated suburbanization (Lorens 2006, 99). Moreover, it soon became clear that the 5year timeline was unrealistic. By 1999, only an estimated 5-10\% of Polish municipalities had drawn up the required "local plans" (Buczek 2013, 10). In Warsaw, less than $40 \%$ of city's territory was covered by a spatial plan. Faced with this enormous backlog, the deadline for voiding the old plans was extended until 2003.

According to sociologist Łukasz Drozda, the 2003 Act on Spatial Planning and Development represented the de facto formalization of the urban-planning regime (2018, 21). It voided the remaining 1985-era spatial plans. Weak and un-constraining of developers though those spatial plans were, now they had no force whatsoever. Since the majority of municipalities still lacked the required "local plans," the 2003 Act introduced an alternative procedure for zoning and issuing building permits, the so-called "“administrative decisions,' which are intended to serve as legally binding planning documents in the areas where there 
is no 'local plan' accepted by the local councils" (Lorens 2006, 99). Thus, land use and permitting became the subjects of ad hoc and often unpredictable decisions by municipal officials. As one Warsaw activist described the situation:

There are no zoning laws here basically. You have [only] one-third of the city that is covered by the zoning laws, and when these laws are being voted on, they are always like, "Put in as many buildings as you can." So, even if there are zoning laws, they are always pro-developer zoning laws. If you have no zoning laws, the city officials can do whatever they want. (Interview W19-12)

As this comment implies, a laissez-faire urban-planning regime need not exclude political corruption. In Piotr Lorens's analysis, the 2003 law created "many opportunities for corruption" because it allowed municipal officials to use ad hoc "administrative decisions" rather than systematic planning to regulate developers $(2006,100)$. The Polish academic and former mayor of one of Warsaw's districts in the 1990s Grzegorz Buczek offers a more neutral analysis, writing that "the simplest explanation of this unexpected behavior of [the] local self-governments [to draw up spatial plans] was [that they were attempting to avoid the] burden of legal and financial obligations which might be created by the new plans" $(2013,10)$. While this may have been part of the explanation, many of my interviewees, especially those engaged in urban activism, suggested that corruption was in fact the simpler explanation (Interviews with W19-2, W19-4, W19-11, W19-12, W19-17). The mismatch between regulatory capacity, as captured by the inadequacy of zoning documents and the potential value of undeveloped lots, served the interests of investors and the politicians who worked with them. Thus, while planning had become more rigorous in theory, in practice it was mostly governed by non-binding studiums and outdated spatial plans. Creating a binding plan that might impose financial burdens on developers was optional — and rarely opted for. As in Prague, the perception that urban planning institutions had been captured by developers fed a sense of grievance whose potential for mobilizing collective action would depend on the POS.

This section has dwelt on similarities and differences in these two urban-planning regimes because they offer the important lesson that the dysfunctions of the post-socialist city may vary in origin (be they hyper-deregulation as in Warsaw or technocratic clientelism as in Prague) and yet have the similar outcome of creating space for urban populist movements. What kind of urban populism emerges is the next sections' subject.

\section{The openness of municipal politics to urban movements}

By the 2010s, both cities' planning regimes were experiencing crises of legitimacy. This section will focus on the other aspect of the POS highlighted as shaping the master frame of city politics: the opportunities for autonomous action within municipal political institutions. These opportunities were greater in Prague than Warsaw.

The year 2010 marked the beginning of the implosion of Prague's ODS political machine (Pixová 2020, 212). A newly founded party TOP '09 took 30 percent of the vote for the city council and was able place one of its members Tomáš Hudeček in the mayor's seat, making him the first non-ODS mayor since 1994. Hudeček's tenure proved brief, but it 
initiated the near-total replacement of the established political elites, not just ODS but also their sometime partners the Social Democrats (Interviews with P18-19 and P19-35). The 2014 elections accelerated this generational replacement. The newly established ANO party, generally described as populist, took a plurality and captured the mayoralty. Another new political formation, the Trojkoalice, brought the locally based Party of Mayors and Independents (STAN) together with a reorganized Green Party into the governing coalition. In the 2018 elections, this trend continued with a win by the Pirates - as postmodern a party as their name indicates - who took the mayor's office. All of the above parties enjoyed national-level reach by 2018 , even if some, like the Pirates, had local grassroots origins. Another party from this new wave, "For Prague" (Praha sobě), was very much Prague-based: it was a new citizen's initiative that began in several central-city neighborhoods in 2014. In 2018, it vaulted into city-wide government. The low level of institutionalization of new parties makes for weaker bonds between municipal state institutions, commercial real-estate interests, and urbanism-oriented civil society organizations. Providing linkages between these elements is a key function of political parties, but Prague's post-2010 party system does not yet provide such linkages-which creates myriad possibilities and opportunities for urban civil society organizations to find political allies and influence policy.

Whereas Prague's party system has seen the breakdown of the established national level parties and the entrance of new challengers, in Warsaw the two main national-level parties, Civic Platform (PO) and Law and Justice (PiS), which were established in 2001, have consolidated their grip on the City Council. Since 2006, the first municipal elections after the unification of Warsaw's central districts, the collective share of these two parties has climbed from 78.1 to 98.4 percent of the council's seats. The liberal PO has occupied the mayor's office since 2006. Warsaw's urban activist reform groups have contested the municipal elections since 2014, but they have only managed to score a handful of wins in the lower-level borough councils (Interviews with W19-4 and W19-17). Facing such entrenched parties, Warsaw's urban-movement organizations have fewer opportunities for autonomous action than Prague's, which inclines them to more radical frames and disruptive tactics.

The strong grip of established parties on Warsaw's political structures is largely due to national-level dynamics, in particular, the intensity of democratic backsliding (interview W19-19). Because backsliding is led by populist-nationalist parties whose voters are concentrated in the countryside, governments in the larger cities become bastions of the liberal opposition. This inclines voters who are concerned about backsliding to favor the strongest opposition candidate in the belief that he or she may be able to challenge the dominant-party candidate on the national stage at some later point (O'Dwyer and Stenberg 2021). This scenario has played out in Warsaw: its current President, Rafał Trzaszkowski of the liberal PO, mounted a surprisingly robust, if ultimately unsuccessful, bid for the national presidency in 2020. To the extent that Warsaw is seen as an incubator for major-party candidates who can challenge PiS, it is hard for locally-based grassroots parties to break into municipal politics. Since the Czech Republic has also experienced democratic backsliding in recent years, the same logic could have applied in Prague; however, two factors appear to work against it. First, the implosion of established political parties in 2010 undermined their credibility as viable challengers to the populist newcomer ANO, on whom Czech backsliding 
is blamed. Second, the Czech Republic's backsliding has been far more gradual and not as extreme as Poland's, which diminishes the urgency of the threat in voters' eyes (Lührmann \& Lindberg 2019).

\section{How urban social movements differed in Prague and Warsaw}

Based on the contextualization of the POS and master frame in both cities, I now describe the range of mobilizing frames and tactical styles employed by their urban activist groups since 2010. To lead with the fundamental point of contrast, the political context in Prague favors groups with reformist frames-i.e. those emphasizing the restructuring of institutions within the established procedures. Groups with more radical frames and more disruptive tactics have fared less well, which tendency has frustrated some observers. For example, the urban geographer Michaela Pixová voices exasperation with Prague activists" "failure" to understand their grievances more radically: "In my research, I discovered Czech citizens and activists rarely criticize the new global form of [neoliberal] political economy... Instead, they frequently see urban problems and controversies a local problem, anomalies in an otherwise well-functioning system" $(2020,29)$. By contrast, Warsaw's more closed POS has favored groups with frames that portray reform as insufficient and the disruptive tactics of the participatory protest organization. None of Warsaw's urban activist groups have achieved the level of policy impact as Prague's, but perhaps the most surprising element for me was the lack of visibility and impact of reformist groups in Warsaw.

\section{Prague}

The three municipal elections since 2010 conveniently chart the evolution of Prague's urban movement. The first period, which followed the 2010 elections, marked the movement's genesis. As described earlier, the implosion of ODS's political machine opened opportunities for a coalition of liberal politicians and architects to propose an ambitious urban planning reform, which came together in 2012 under the rubric "Metropolitan Plan" (MP henceforth). The 2014 elections broadened the urban movement as a local citizen's initiative For Prague was founded and other political parties entered the public debate about the MP. Besides for Prague, an ecosystem of smaller, less party-like groups have organized around urbanist issues since 2010, from less formalized urban planning circles (e.g. Prague Watch and architects' networks) to environmentalist groups (e.g. Arnika and AutoMat) to neighborhood-level protests targeted against such actions as plans to close a local school (interviews P18-26, P18-17, P18-20, P19-42). Some groups took more radical positions: the local Green party, in particular, built links to grassroots groups with anti-growth or NIMBYstyle goals (interview P19-42). This broadening of the movement field brought a range of framings, from reformist to radical, into the political arena and, at times, disruptive and confrontational tactics. In this context, the 2018 elections can be seen as a moment in which the resonance of these different mobilizing frames was publicly tested; ultimately, they winnowed the movement field, as more radical urbanist frames lost ground to reformist ones.

To begin with the 2010 elections, these elections brought Tomáš Hudeček, a politician from TOP '09 and a geographer by training, to the City Council. Architects, academics, and other experts were calling for a new approach to urban planning based on flexible, multi-function zoning, replacing the baroquely complicated functional-planning 
model whose main features retained many continuities with the pre-1989 system (MR 2017, 99). As an urban geographer, Hudeček took a deep interest in city development and organized an expert-based reform coalition (Pixová 2020, 158). On July 12, 2012, the City Council voted to drop "Concept 2009," abandoning several years of URM work and "symbolically reach[ing] the dead end of the functional conception of planning" (Kancelár 2014, 206). Shortly thereafter, the Council created an independent research division within URM called the Office of the MP. Román Koucký, an architect with experience designing master plans for other Czech cities, was appointed the Office's head. When Hudeček became mayor in 2013, Koucky's team had the full institutional resources of City Hall behind them. To accentuate the break with the functional planning past, the URM was dissolved and replaced with a new institution, the Institute for Planning and Development (IPR henceforth). Optimism ran high, and Koucký declared that the MP would soon be ready (MR 2017, 26).

Many of my interviewees recalled Hudeček's term as the MP's "golden age" (cf. MR 2017, 101). In transforming the URM into IPR, many senior planning officials were edged out and replaced with a younger generation of architects. One architect recalled, "It was like a small Velvet Revolution. The ice was melting, and you met people keen on cooperating, at least within the institution. So, there were, I think, big expectations about what would happen" (Interview P18-26). The research behind the MP was a massive project, extending beyond the IPR itself to include a team of over 60 people at the Czech Technical University and generating thousands of pages of methodologies and conceptual materials. The latter were particularly striking, for they included as much philosophical and aesthetic argumentation about the nature of planning as they did "hard data" about Prague as a city. In addition to this work, the IPR prepared a new strategic plan for the city and a Manual for Public Spaces. It also created more public information about planning, opening a handsome new information center with public talks and exhibitions. All of this would have been hard to imagine just a few years earlier.

The 2014 municipal elections broadened the urban reform coalition, but in doing so, introduced tensions that threatened to break it apart. Entering the city council and governing coalition were ANO, a populist party with an amorphous anti-corruption program, the Greens, and the Party of Mayors, so called because it comprised municipal-level politicians from across the country. (It also had strong ties to the architects and experts who had worked with IPR on the MP.) ANO took over the mayorship, while the Greens took over the city's land-use planning portfolio and actively inserted themselves into the drafting of the MP. All of these groups endorsed a restructuring of the urban-planning regime, in particular, a restructuring of the functional planning framework, but the Greens were deeply suspicious of Koucký's vision of increased flexibility in planning.

Two of the most visible frames employed in the debate about the MP closely fit the anti-system type: an anti-communism frame used by Roman Koucký's inner circle in the Institute for Planning and Development and an anti-neoliberalism frame employed by the Green Party. Most actors, however, framed the MP in a more pragmatic and policy-oriented way, i.e. the reformism frame. It is always difficult to gauge frame resonance, but the 2018 municipal elections, which followed several years of deadlock among groups employing these different frames, suggest that both anti-communism and anti-neoliberalism found little wider resonance. Before moving to those elections and the contours of the urban movement 
after them, I first lay out the framing debate between 2014 and 2018.

The reformist frame presented the MP in terms of solving specific policy problems, e.g. increasing density, containing sprawl, improving public spaces, heritage protection, ecological sustainability, and housing affordability. In this framing, the MP's central contribution is defined as bringing flexibility and stability to land-use and permitting. The extant urban-planning regime is faulted for necessitating multiple changes to build anything, so that getting these changes through City Hall delays construction (while inviting corruption). More flexible planning would obviate constant changes to the master plan and thus increase the stability of planning rules.

The MP's sharpest critics and strongest supporters framed their arguments less in terms of policy fixes and more in terms of uprooting deep systemic issues. For the critics, i.e. the Greens, this was neoliberalism. Michaela Pixová provides the best summary of this critique when she writes:

In his Metropolitan Plan, Roman Koucký reduces regulations to an essentially artistic design of the physical size of the built environment in different parts of the city and proposes only four categories of functional use (as opposed to the current more than thirty functional categories and additional subcategories). In other words, Koucký essentially replaced previous rigid technocratic regulations with deregulation, which would provide less opportunities for political corruption but also much wider freedom to the developers themselves. (Pixová, 2020, p. 44)

Pixová also writes, "The debate [about urbanism] nonetheless to a large extent ended up seized by architects, the development lobby, and discourses promoting urban renewal and gentrification" $(2020,158)$.

Against criticism that flexibility would give free rein to developers, threaten Prague's green spaces, and even increase corruption in the real-estate market, Koucký and his circle of architects responded by redefining "flexibility" into "anti-dirigisme," into "antistatism," into "anti-communism." This progression toward an increasingly radical urbanist frame is evident in comparing Koucký's public statements over the period from 2012 to 2016. During IPR's “golden age," Koucký tended to present the functional planning model's roots as deeper than the communist period. As he stated in 2012, "We still have a land-use planning system founded on 1970s-era methods. It's a vulgarized version of the Athens Charter, which is based on mono-functional zones and the segregation of transport" (MR 2017, 7). However, as the IPR's inner circle began to encounter criticism from the Greens and others, "anti-dirigisme" became "anti-communism." Not only was the extant planning system a communist-era relic, so were the MP's critics. In October 2016, Koucký railed against an unnamed clique of activists in polarizing language for blocking the MP:

[I]t's quite evident that there exists a kind of "tribe of hate" ... They are people who have never created anything, whose goal is the destruction of others' work. They are united with the post-Bolshevik urbanist forces who are trying tooth and nail to keep central planning alive.... We must also realize that those trying to destroy the [Metropolitan] Plan are those who are fully responsible for the state of the Czech cities today because they've been their planners since the 1970s. (MR 2017, 78, emphasis added). 
Between 2014 and 2018, not only the MP but IPR's existence itself came into question, as the local Greens employed sharp tactics against its alleged neoliberalism. Here is one description from the IPR's own materials: "Green Party members undertook an illconceived plan to torpedo documents produced by IPR. This brought an explosively destructive form to the public discussion [of the MP] in which the conceptual documents were attacked, as well as individual IPR representatives themselves" (MR 2017, 102). In this period IPR's head was changed four times. (In the fragile coalitional politics in City Hall, the deputy for territorial development [náměstek pro územnií rozvoj] was changed three times.) IPR was under constant threat of audit, which could have shut it down (interviews P18-18, P18-12). In 2016, in the midst of this infighting, the deputy for territorial development in City Hall took the extraordinary step of forbidding IPR from publicly discussing the draft MP. This ban lasted for almost two years (MR 2017, $67 \& 104$ ).

Thus, the 2018 municipal elections followed several years in which urban activism had become bound up in a polarized debate around the MP. The loudest voices-Koucký's architectural circle and the Greens - framed starkly opposed visions of urbanism, either in terms of uprooting communism's legacy via the MP or stopping neoliberalism's entrenchment by opposing it. Neither of these radical frames showed much wider resonance in the elections. The Greens did not receive enough votes to reenter the City Council, and Koucký's campaign for the MP seemed stalled.

The elections rewarded groups with more reformist mobilizing frames. The Pirates, who won the mayoralty, espoused a kind of do-it-yourself populism that tended to gravitate toward technological fixes for politics, e.g. "smart cities" etc. However, the most dramatic evidence of the resonance of the reform-populist frame was the strong showing of For Prague. It had begun as a citizens' initiative in the Prague 7 neighborhood in which a local school teacher gathered signatures to block plans by the neighborhood council to construct a new town hall-plans which were criticized as non-transparent and wasteful (interview P19-40). One respondent noted that Prague 7's compact, walkable scale facilitated the doorto-door canvassing on which For Prague was built (interview P19-42). Following this petition's success, For Prague transformed itself into a grassroots political party, winning the local elections in Prague 7 in 2014 and then building branches in other districts of Prague. The party concentrated on everyday annoyances, not grand policy. As one For Prague activist put it:

We were annoyed by lots of little things, it was a catastrophe. Everything was taking forever. Take cleaning, for example... The city was paying for some cleaning services which were supposed to do cleaning in Prague 7, but no one ever saw the cleaning company...You cannot solve these problems at the level of the district, things like homelessness...So, we realized that if things are to improve in Prague 7, especially the things we were most concerned about, we could not do anything about them without also changing municipal authorities. (Quoted in Pixová 2020, 134).

In contrast to its counterpart The City Is Ours in Warsaw, For Prague's was a bottomup, reformist-populist frame. As one member told me, "[For Prague] is a lot about people who you trust and who have a shared vision. The vision is not very clear in left-right terms and is a lot about practical solutions...It's definitely anti-corruption, but this is like one aspect of its functioning. It is also a lot about Prague 7 and urban planning and ecological 
protection" (interview P19-40). Despite its origins as a movement that ousted Prague 7's previous elites, a common observation across my interviews was that For Prague was a willing partner with other municipal institutions, particularly IPR (interviews P19-36, P1937, P19-28; cf. Pixová 2020, 168). Even among other groups, including those critical of the MP, I also encountered this reformist logic. After criticizing the missteps of IPR and problems of the MP, one architect active in urban planning circles stated, "It's very important that the city has such an institution [as IPR], and I think it's very good the institute was able to withstand the attempts to dismantle it" (P18-26). An activist from the group Automat followed a critique of the MP as excessively neoliberal with, "We don't want to destroy the Plan, we want to change it" (Interview P18-20).

At the time of my second round of interviews in 2019, a new government had been installed comprising the Pirates, For Prague, and the Party of Mayors. A pragmatic attitude toward the MP prevailed in my conversations with For Prague representatives (interviews with P19-36 and P19-37), and relations between City Hall and the IPR had been repaired. For the winners of the 2018 elections, urbanism's focus had turned to improving the city, not remaking it.

\section{Warsaw}

As in Prague, my Warsaw respondents emphasized that social movement organizations focused on urbanism and the city space as such only rose to prominence around 2010 (see also Walter 2006, 260). Though not the very first such organization, certainly the most visible was The City Is Ours (Miasto Jest Nasze), which began in 2013 as a locally based initiative to prevent the redevelopment of the Jazdów area in central Warsaw, which is an unique settlement of rough-and-ready barracks-style dwellings constructed after WWII to house the workers who rebuilt Warsaw after its near total destruction in the war. The settlement is located in a forgotten enclave in one of the city's most desirable locations, right between the national parliament and the former royal gardens, Łazięnki Park. Originally the spartan structures were intended as temporary, but over time, they were occupied by artists and intellectuals, who leased them inexpensively from the city. The settlement remains today, retaining its character as an area untouched by development, either socialist or freemarket. By the 2000s, however, its commercial potential attracted considerable interest from investors, and the city government readied plans for its redevelopment. The City Is Ours began as a residents' revolt against these plans, which was call Open Jazdów (Otwarty Jazdów). It drew supporters from across the city, who came to join the residents in public events, workshops, and improvement projects to preserve this historic enclave. In this stage, the organization was very much a participatory protest organization. My respondents recalled those early days in terms of a bottom-up community built of very disparate elements who were united not by ideology but local pride. Respondents described the protest as a kind of living experiment demonstrating the kind of sustainable and humane city that Warsaw should be, with participatory decision-making, green lifestyles, and so on. One respondent called it a "kibbutz" (Interview with W19-12). The activists were successful in blocking the development, a result that strongly boosted the movement. As one interviewee recalled, "This was one of the biggest achievements of our movement: that we protected the houses [in the settlement] and that we proved that we can stop this mechanism of destroying 
everything in order to make money" (Interview with W19-12).

Before long, however, a more radical leadership emerged in the person of the charismatic activist Jan Śpiewak, who framed the fight for Jazdów as a symbol of the larger issue of "wild reprivatization" (dzika reprywatyzacja). This term refers to the highly contentious issue of properties owned by the state and their privatization by the municipal governments after 1989. Because of Warsaw's destruction during WWII and its rebuilding by the survivors, it is very difficult to sort out property claims. Often the original owners and their relatives are deceased. Records are missing. Competing claims exist, and the current residents argue that they built and maintained the buildings standing today. Patchwork legislation on the issue has created lots of legal uncertainty about ownership, and has even led to a secondary, speculation-fueled market in the sale of such property claims among developers. Highly publicized cases in which life-long residents were evicted by politicallyconnected investors with dubious ownership claims made reprivatization a kind of emblem of the larger issue of corruption and political clientelism in the transition (Drozda 2018, 131134).

Warsaw Is Ours' radical mobilizing frame portrayed the city's problems as beyond the scale of targeted reforms and conventional political tactics. As one of its former leaders told me: "I see this [urban activism] through these lenses. I believe that all the problems of democracy come from this fucking neoliberal agenda to destroy everything to make the money class even richer" (Interview with W19-12). The City Is Ours also framed Warsaw's governing elites, the Civic Platform (PO), who are the mainstay of liberalism in contemporary Poland's current political order, as in cahoots with monied interests regarding reprivatization. The respondent quoted above called PO the "extreme center." This language is particularly strong given that PO is the strongest rival to PiS, the populist illiberals who have led Poland's democratic backsliding since 2015.

The City Is Ours' disruptive and confrontational tactics reflected this framing. In 2014, it supported a campaign to recall the President of Warsaw, who was a member of PO. The group faulted PO for ignoring them and neglecting Warsaw's urbanist problems. Its stance was an attempt to pressure PO, but the recall referendum, which was also supported by Law and Justice, failed. A second tactic adopted around this time was to launch a highly public investigation into corruption in the reprivatization process: the group created a website called the Reprivatization Map of Warsaw in which it published details about suspect cases and those involved. The website resulted in the group, and Jan Śpiewak in particular, facing multiple law suits and possible criminal penalties. In the eyes of many I spoke with, these tactics had backfired against The City Is Ours. On the one hand, it drove those concerned more with policies like housing and the environment than reprivatization out of the organization; on the other, it motivated PO to take up some of the group's less polarizing agenda items, but without its cooperation (Interview with W19-11).

In 2016, The City Is Ours voted out Jan Śpiewak as leader, precipitating an acrimonious split in the movement. Śpiewak immediately founded a new group Warsaw Wins (Wygra Warszawa). The City Is Ours changed its focus to more pragmatic policies, especially regarding traffic, and though it remained the most recognizable name on urbanmovement issues, it seemed to lose its populist appeal. As one interviewee commented, "It's all soft. And he [Śpiewak] was against that. He was very much for the sharp edge" (Interview 
W19-17). The cost of these divisions became evident in the 2018 city elections, which saw both The City Is Ours and Warsaw Wins put up separate party lists. Despite results that collectively would have put them in third place, neither gained any seats in the City Council because they competed against each other. Across my interviews, it was clear that these results were very deflating for urban activists in general, raising doubts about the efficacy of the movement.

Like Prague, Warsaw's urban movement field included actors with both radical and reformist mobilizing frames. The differential resonance of these frames across the two contexts reflected variation in the accessibility of municipal institutions: Warsaw's closed system lent greater resonance to radical frames, while the opposite was true in Prague.

\section{Conclusion}

In a decade in which national-level populist parties have made large gains across East Central Europe, this paper has analyzed the consolidation of grassroots movements challenging entrenched elites in two of the region's capitals. I examine why these urban movements have become an important feature of municipal politics in Prague and Warsaw, but also the factors that determine the mobilizing frames and strategic orientations such movements adopt. I find that, although the mobilizing grievances of both cities' urban movements were the product of how post-socialist urban-planning regimes developed-in particular their lack of responsiveness and the perceived corruption on local elites - the urban movements' predominant frames are quite different in Prague and Warsaw. This is because of differences in the POS and its associated master frame. Prague's urban populism has found greatest resonance when it has used mobilizing frames emphasizing the reform of existing institutions and familiar political tactics. By contrast, in Warsaw more radical populist frames have found greater resonance and disruptive, confrontational tactics (such as supporting PiS's efforts to recall Warsaw's President and targeting individuals with corruption charges on the internet) have been used. Prague's urban movements have found partners and positions within municipal politics (even if at the cost of incumbent elites), whereas Warsaw's suffer from insider-outsider dynamics and internal fragmentation.

Beyond shedding light on a type of social movement that has received scant attention in the comparative scholarship (Jacobssen 2015, 1), these findings can contribute to ongoing debates in the study of post-socialist politics and cities. First, they add to a body of scholarship challenging the prevalent characterization of East European civil society as quiescent and overly-dependent on international donors (Polanska 2015, 195). Second, for the study of the post-socialist city, this research shifts the analytical focus from the legacies of the "socialist city" to the opportunities (and constraints) presented by contemporary political conditions, in particular the accessibility of political institutions to new actors. While socialist legacies continue to matter, this analysis suggests the need for attention to the role of political opportunity structure in explaining variation among social movements after communism. A third contribution is to broaden the scope of scholarship on populism in East Central Europe, a scholarship which has overwhelmingly focused on the radical-right and xenophobic populism of parties such as Poland's Law and Justice and Hungary's Fidesz. That brand of populism, which is based in cultural backlash, draws its base primarily from outside the larger cities; this has led scholars to neglect the possibility of progressive, 
socioeconomic populist movements (Mudde and Rovira Kaltwasser 2013, 495-496) in the urban centers. Progressive populists are more likely than their radical-right counterparts to address the kinds of ongoing issues that East Central European cities face, such as touristification, climate change, and affordable housing; therefore, it is important to understand how they tend to frame such issues and the strategic-tactical repertoire that they employ.

\section{References}

Benford, Robert and Snow, David. 1992. "Master Frames and Cycles of Protest," In A. Morris and C. McClurg Mueller (eds.) Frontiers in Social Movement Theory. New Haven: Yale University Press, 133-55.

Buczek, Grzegorz. 2013. "The Spatial Planning System: The Transition from a centrally planned to a market economy, Poland - 1989-2013." Unpublished manuscript.

Davies, Norman. 2005. God's Playground: A History of Poland. Vol. 1. Oxford: Oxford University Press.

DeLeon, Richard and Powell, Sandra. 1989. "Growth Control and Electoral Politics: The Triumph of Urban Populism in San Francisco.” The Western Political Quarterly 42(2): 307-331.

Diani, Mario. 1996. "Linking Mobilization Frames and Political Opportunities: Insights from Regional Populism in Italy." American Sociological Review 61: 1053-69.

Diani, Mario and Donati, Paolo. 1999. "Organisational Change in Western European Environmental Groups: A Framework for Analysis." Environmental Politics 8(1): 13-34.

Drozda, Łukasz. 2018. Dwa Tysiace: Instrukcja Obstugi Polskiej Urbanizacji w XXI Wieku [A User's Manual for Polish Urbanization in the $21^{\text {st }}$ Century]. Warsaw: Fundacja Bęc Zmiana.

Ferenčuhová, Slavomíra. 2016. "Explicit Definitions and Implicit Assumptions about PostSocialist Cities in Academic Writings." Geography Compass 10(12): 514-524.

Guasti, Petra. 2016. "Development of citizen participation in Central and Eastern Europe after the EU enlargement and economic crises." Communist and Post-Communist Studies 49(3):, 219-231.

Hirt, Sonia. 2012. Iron Curtains: Gates, Suburbs and Privatization of Space in the PostSocialist City. Oxford and Malden: Wiley Blackwell Press.

----. 2013. "Whatever happened to the (post)socialist city?" Cities 32: 529-538.

Hoffman, Lily. 1994. "After the fall: Crisis and renewal in urban planning in the Czech Republic.” International Journal of Urban and Regional Research 18(4): 691-702.

Horak, Martin. 2007. Governing the Post-Communist City: Institutions and Democratic Development in Prague. Toronto: University of Toronto Press.

Jacobsson, Kerstin. 2015. "Introduction: The Development of Urban Movements in Central and Eastern Europe," In Kerstin Jacobsson (ed.) Urban Movements in Central and Eastern Europe. Burlington, VT: Ashgate, 1-32.

Kanceláŕ metropolitního plánu. 2014. Metropolitní plán: Koncept odůvodnění [The Metropolitan Plan: Conceptual Justification]. Prague: Institut plánování a rozvoje.

Koucký, Roman. 2017. Metropolitni rozhovory 2012/2016. (MR) [Metropolitan Conversations: 2012-2016] Prague: IPR Praha.

Kusiak, Joanna. 2017. Chaos Warszawa: Porzadki Przestrzenne Polskiego Kapitalizmu [Chaos Warsaw: Spatial Orders of Polish Capitalism]. Warsaw: Bęc Zmiana.

Lorens, Piotr. 2006. "Trends and Problems of Contemporary Urbanization Processes in Poland," In Uwe Altrock, Simon Güntner, Sandra Huning, and Deike Peters (eds.) Spatial 
Planning and Urban Development in the New EU Member States: From Adjustment to Reinvention. Burlington, VT: Ashgate, 95-111.

Lührmann, A. and Lindberg, S. (2019). "A Third Wave of Autocratization is Here: What is New About It?” Democratization 26(7): 1095-1113.

Maier, Karel. 1998. "Czech planning in transition: Assets and deficiencies." International Planning Studies 3(3): 351-365

Mudde, Cas and Rovira Kaltwasser, Cristóbal. 2013. "Populism," In Michael Freeden and Marc Stears (eds.) Oxford Handbook of Political Ideologies. Oxford: Oxford University Press, 493-510.

Musil, Jiří. 2005. "City development in Central and Eastern Europe before 1990," In F.E. Hamilton, Kaliopa Andrews, and Nataša Pichler-Milanović (eds.) Transformation of Cities in Central and Eastern Europe. Tokyo: United Nations University Press, 22-43.

O’Dwyer, Conor and Stenberg, Matthew. 2021. "Local-Level Democratic Backsliding? The Consolidation of Aspiring Dominant-Party Regimes in Hungary and Poland." Government and Opposition, 1-24. doi:10.1017/gov.2021.12

Pixová, Michaela. 2020. Contested Czech Cities: From Urban Grassroots to Pro-democratic Populism. Singapore: Palgrave Macmillan.

Polanska, Dominika. 2015. "Alliance Building and Brokerage in Contentious Politics: The Case of the Polish Tenants' Movement," In Kerstin Jacobsson (ed.) Urban Movements in Central and Eastern Europe. Burlington, VT: Ashgate, 195-217.

Roubal, Petr. 2019. "Plánování Prahy v 80.-90. Letech: Sebedestrukce urbanistické expertizy," In Michal Kopeček (ed.) Architekti dlouohé změny: Expertní kořeny postsocialismu $v$ Československu [Architects of the Long Transformation: The Expert Roots of Postsocialism in Czechoslovakia]. Prague: Argo, 315-354.

Stanilov, Kiril and Sýkora, Luděk. 2012. "Residential Growth in Metropolitan Prague." Journal of Architectural and Planning Research. 29(4): 278-291.

Sýkora, Luděk and Bouzarovski, Stefan. 2012. "Multiple Transformations: Conceptualising the Post-communist Urban Transition." Urban Studies 49(1): 43-60.

Sýkora, Luděk and Mulíček, Ondřej. 2014. "Prague: Urban Growth and Regional Sprawl," In Kiril Stanilov and Luděk Sýkora (eds.) Confronting Suburbanization: Urban Decentralization in Postsocialist Central and Eastern Europe. John Wiley \& Sons, 133162.

Tarrow, Sidney. 1994. Power in Movement. New York: Cambridge University Press.

Walter, Mareile. 2006. "Problems of Urban Planning in Warsaw," In Uwe Altrock, Simon Güntner, Sandra Huning, and Deike Peters (eds.) Spatial Planning and Urban Development in the New EU Member States: From Adjustment to Reinvention. Burlington, VT: Ashgate, 259-269. 


\section{Appendix: Notes on the Interviews}

The interview data used in this article were gathered in two fieldwork trips to Prague (JuneAugust 2018 and July-August 2019) and one to Warsaw (June 2019). The interviews followed a semi-structured format, and typically lasted from one to two hours. In order to give the respondents freedom to reflect critically on city politics and planning, I promised them anonymity. Respondents were primarily recruited through the snowball method, meaning that after each interview, I asked the respondent to suggest other contacts relevant to the topic. I supplemented this recruitment strategy with targeted requests at institutions of urban planning and other relevant municipal offices. As captured in Table A1, I tried to make sure that each city's respondent pool included people with either expertise or direct experience in urban planning, urban development, municipal politics, and urbanist activism. Most respondents had direct experience or expertise in more than one field - say, as an activist and then a politician. As two notes on the table's categories, "outside expert" includes academics, journalists, or members of think tanks. "Other" includes respondents who were deeply engaged with city politics or urban issues but did not consider themselves activists per se and did not fit any of the other categories in the table.

Table A1: Attributes of the Interview Sample by City

\begin{tabular}{r|c|c|c|c}
\hline & \multicolumn{2}{|c|}{ Warsaw } & \multicolumn{2}{c}{ Prague } \\
\hline & $\begin{array}{c}\text { Number of } \\
\text { Interviews }\end{array}$ & $\%$ of Total & $\begin{array}{c}\text { Number of } \\
\text { Interviews }\end{array}$ & $\begin{array}{c}\% \text { out of } \\
\text { Total }\end{array}$ \\
\hline Interviews in total & 22 & & $44 *$ & \\
\hline ..Of these: & & & & \\
\hline 2018 & 22 & $100 \%$ & 17 & $39 \%$ \\
\hline Momen & 5 & $23 \%$ & 14 & $32 \%$ \\
\hline Men & 17 & $77 \%$ & 30 & $68 \%$ \\
\hline Under 40 yrs. old & 13 & $59 \%$ & 16 & $36 \%$ \\
\hline Over 40 yrs. old & 9 & $41 \%$ & 28 & $64 \%$ \\
\hline $\begin{array}{r}\text { Have experience } \\
\text { as... }\end{array}$ & & & & \\
\hline Activist & 12 & $55 \%$ & 12 & $27 \%$ \\
\hline City official & 10 & $45 \%$ & 13 & $30 \%$ \\
\hline Outside expert & 9 & $41 \%$ & 16 & $36 \%$ \\
\hline $\begin{array}{r}\text { Architect or } \\
\text { developer }\end{array}$ & 6 & $27 \%$ & 18 & $41 \%$ \\
\hline Politician & 2 & $9 \%$ & 9 & $20 \%$ \\
\hline Urban planner & 8 & $36 \%$ & 13 & $30 \%$ \\
\hline Other & 0 & $0 \%$ & 5 & $11 \%$ \\
\hline
\end{tabular}

Notes: *Four of the interviewees in Prague were interviewed in both 2018 and 2019. 